\title{
TANGGUNG GUGAT NOTARIS TERHADAP AKTA YANG BERASAL DARI DATA YANG TIDAK BENAR
}

\section{Dedi Purwandi}

Program Magister Kenotariatan Fakultas Hukum Universitas Lambung Mangkurat. Jl.Brigjend H. Hasan Basri Komplek Banjarmasin 70123 Indonesia Fax:05113307877+E-mail :petrukakang@yahoo.co.id

Submitted: 20/09/2017; Reviewed:22/09/2017; Accepted: 29/09/2017

\begin{abstract}
This research aims at studying and analyzing the ratio legist of the provision on the double position of the Notary Publics as stipulated in Article 17 of Act Number 2 of 2012 concerning Notary Public's Office and analyzing the provision of Article 93 paragraph (1) of Act Number 40 of 2007 concerning Limited Company in relation with the position of the Notary Public as Director. This is normative legal research by conducting library study mainly secondary legal resources. This research applies statute approach by studying all acts and regulations related with the legal issue being dealt with. The nature of this research perspective analytical, i.e. to explain precisely the characteristics of an individual, condition/phenomena of the groups in order to determine the spread of a phenomenon and to determine the existence of relation between one phenomenon to the order in the society. The results of this research are firstly, the ratio legist of the provision on the double position of the Notary Public as stipulated in Article 17 of Act Number 2 of 2014 concerning Notary Public's Office is to avoid double position which may lead to conflict of interest. If a the Notary Public has double position as director, it is clear that there are differences the Notary Public of authorities, and this may cause abuse of power. Secondly, a Notary Public holds a position as a director as stipulated in Article 93 paragraph (1) of Act Number 40 of 2007 concerning Limited Company is not possible. Articles 17 of Act Number 2 of 2014 concerning Notary Public's Office prohibits double position. Limited Company Act does not explicitly mentions about double position in a Limited Company, but it is clearly done because the tasks and authorities of a Notary Public and a Director are very district and double position may bring about conflict of authorities.
\end{abstract}

Keywords : Liability; Notary Public; Deed; Untrue Data

Abstrak: Notaris diangkat menjadi pejabat Negara dalam menjalankan jabatannya 
berkewajiban, jujur, seksama, mandiri dan tidak berpihak dan menjaga kepentingan pihak dalam melakukan perbuatan hukum, Pasal 16 huruf a Undang - Undang Nomor 2 Tahun 2014 tentang Jabatan Notaris. Terkait dengan tanggung gugat Notaris dalam pembuatan akta serta akibat hukumnya dari akta, yang sebab data diri berupa identitas dan foto dalam buku nikah dipalsukan pihak penghadap. Tujuan dari penelitian inni untuk mengetahui tanggung gugat Notaris ketika menuangkan kehendak para penghadap yang memalsukan data diri mereka, sekaligus untuk mengetahui akibat hukumnya.Kegunaan penelitian ini adalah sebagai bahan acuan bagi Notaris agar lebih berhati - hati dalam menjalankan profesi jabatannya dan guna di kemudian hari agar tidak menimbulkan masalah bagi Notaris.Metode yang digunakan dalam penelitian ini menggunakan hukum normatif dengan tipe penelitian doctrinal research yangdigunakan untuk memperjelas suatu aturan hukum dibidang tertentu, dengan menggunakan bahan hukum primer dan sekunder yang dikumpulkan dan diolah dalam studi kepustakaan, yang mana untuk member kejelasan mengenai tanggung gugat Notaris terhadap akta yang berasal dari data yang tidak benar. Pendekatan yang digunakan dalam penelitian ini pendekatan perUndang - Undangan (statue approach), pendekatan konseptual (conceptual approach), penelitian ini bersifat analisis preskriftif yaitu mempelajari tujuan hukum, nilai nilai hukum, aturan hukum dan konsep hukum.Kesimpulan pada rumusan masalah pertama tanggung gugat Notaris terhadap akta yang berasal dari data yang tidak benar ialah digugat dan turut tergugat, namun hanya sekedar saksi dalam persidangan guna untuk pembatalan akta otentik yang telah dibuatnya, melalui putusan pengadilan tersebut.

Kata Kunci : Kewajiban; Notaris; Akta; Untrue Data

\section{PENDAHULUAN}

Pasal 1 angka 1 UUJN menyebutkan bahwa Notaris adalah "Pejabat umum yang berwenang untuk membuat akta otentik dan kewenangan lainnya sebagaimana dimaksud dalam Undang - Undang ini”. Ketika penghadap suami istri datang kepada Notaris, untuk Notaris membuatkan atau menuangkan kehendak suami istri tersebut dalam bentuk akta. Hal yang dilakukan Notaris ialah salah satunya meminta data diri suami istri di antaranya identitas (KTP) dan bukti nikah berupa buku nikah suami istri serta syarat - syarat formil yang diminta Notaris, sesuai dengan akta yang dikehendaki suami istri tersebut dan sesuai dengan peraturan UUJN. Tentunya diminta untuk menunjukkan buku nikah yang asli dari suami istri tersebut, dan disesuaikan dengan identitas (KTP) suami istri yang datang kepada Notaris.

Jika yang terjadi, foto istri yang sah di dalam buku nikah, diganti dengan wanita lain yang dibawa oleh suami dari istri yang sah, guna persetujuan istri terhadap suatu akta yang ingin dibuatnya di hadapan Notaris, demikian terjadi karena istri sah dari suami tersebut tidak menyetujui atas keinginan suaminya, maka suaminya membawa wanita lain beserta identitas (KTP) wanita tersebut, yang disamakan dengan nama istri sah yang sesuai 
dengan data diri istrinya di dalam buku nikah, juga sekaligus menggantikan foto istri yang sah dengan wanita lain yang dibawa suaminya ketika menghadap kepada Notaris.

Hal ini tanpa diketahui Notaris tentang data diri penghadap yang ternyata menggunakan data diri palsu dari penghadap, dan Notaris membuatkan akta yang dimintakan penghadap berkaitan dengan keinginan atau kehendak penghadap tersebut, sehingga akta ini tersandung hukum, karena istri yang sah menggugat haknya serta dia tidak memberikan persetujuan atas dibuatnya akta tersebut. Notaris, yang membuatkan akta itu menjadi turut tergugat ketika diperkarakan di pengadilan, yang sebenarnya Notaris melakukan tugasnya atas kehendak pihak penghadap, dan secara syarat formil memang sudah sesuai dengan anjuran UUJN. Dengan adanya masalah ini maka Notaris dimintakan tanggung gugat terhadap akta yang dibuatnya baik tanggung gugat dalam bentuk perdata, administrasi, maupun dalam bentuk pidana.

Notaris diminta bertanggung gugat atas isi akta bila ada pihak penghadap yang menggunakan data diri berupa buku nikah dan identitas yang dipalsukan, meski Notaris tugasnya hanya menuangkan apa yang dikehendaki oleh para pihak yang datang ke Notaris. Undang - Undang Nomor 2 Tahun 2014 Perubahan atas Undang - Undang Nomor 30 Tahun 2004 Tentang Jabatan Notaris, tidak mengatur secara jelas bagaimana tanggung gugat Notaris terhadap akta yang datanya berupa buku nikah dan identitas yang dipalsukan dari penghadap, dan bagaimana akibat hukumnya, sedang Notaris tugasnya memberikan bukti otentik yang dikehendaki para pihak saat menghadap Notaris, tentang perbuatan atau kenyataan yang terjadi di hadapan Notaris sewaktu perbuatan akta dilakukan.

\section{METODE}

Dalam penelitian ini, menggunakan jenis penelitian hukum normatif. Menurut M. Hadin Muhjad yang dimaksud dengan penelitian hukum normatif adalah penelitian yang mengkaji persoalan hukum dari sudut pandang ilmu hukum secara mendalam terhadap norma hukum yang dibentuk. ${ }^{1}$ Penulis memilih tipe penelitian doctrinal research yaitu secara sistematisasi mengkoreksi dan memperjelas suatu aturan hukum yang berlaku pada bidang hukum tertentu dengan cara melakukan analisis terhadap teks yang bersifat autoritatif yang meliputi bahan hukum primer dan sekunder. $^{2}$ Adapun sifat penelitian yang digunakan penulis yaitu Penelitian ini bersifat (analisis preskriftif) yaitu mempelajari tujuan hukum, nilai - nilai keadilan, aturan hukum, konsep - konsep hukum dan norma - norma hukum. $^{3}$

Dalam hal ini penulis menganalisis tentang tanggung gugat Notaris terhadap akta yang berasal dari data penghadap yang tidak benar, dengan mengganti foto istri yang sah didalam buku nikah dengan wanita lain serta memalsukan identas berupa KTP saat menghadap kepada Notaris. pendekatan yang digunakan sesuai dengan rumusan masalah dalam penelitian ini adalah pendekatan perundang - undangan (Satute Approach) dan pendekatan konseptual (Conceptual Approach). Pengumpulan bahan hukum yang digunakan dalam penelitian ini menggunakan studi ke-

1 M.Hadin Muhjad dan Nunuk Nuswardani, 2012. Penelitian Hukum Indonesia Kontemporer, Yogyakarta : Genta Publising, hlm 9

2 Dyah Ochtorina Susanti dan A'an Efendi, 2014. Penelitian Hukum (Legal Research), Jakarta ; Sinar Grafika, hlm 15.

3 Pieter Mahmud Marzuki. 2010 Penelitian Hukum, Jakarta : Kencana, hlm 22 
pustakaan (library research).Pengolahan dan analisis bahan hukum ini dilakukan secara kualitatif dimana semua bahan terkumpul secara lengkap baru kemudian dianalisis dan digabungkan, untuk menjawab pertanyaan atau isu hukum yang telah dirumuskan dalam rumusan masalah.

\section{ANALISIS DAN PEMBAHASAN}

Tanggung Gugat Notaris Terhadap Akta Yang Berasal Dari Data Yang Tidak Benar

Kedudukan Notaris Sebagai Pejabat

\section{Umum yang Berwenang Membuat Akta}

Kedudukan Notaris sebagai Pejabat Umum yang berwenang membuat akta otentik dan kewenangan lainnya, sebagaimana dimaksud dalam Pasal 1 ayat 1 Undang - Undang Nomor 2 Tahun 2014 Tentang Perubahan atas Undang - Undang Nomor 30 Tahun 2004 Tentang Jabatan Notaris. Pasal 1868 BW" suatu akta otentik ialah suatu akta yang dibuat dalam bentuk yang ditentukan Undang - Undang oleh atau di hadapan pejabat umum yang berwenang untuk itu di tempat akta itu dibuat".Pasal 1870 dan 1871 KUHPerdata "Akta otentik adalah alat pembuktian yang sempurna bagi kedua pihak dan ahli waris, sekalian orang yang mendapat haknya dari akta tersebut memberikan kepada pihak - pihak suatu pembuktian yang mutlak".

Dalam hal ini tugas jabatan Notaris yaitu sebagai pembuat akta otentik yang oleh atau di hadapan Notaris atas permintaan para pihak untuk menjamin segala hak dan kewajibannya ke dalam akta otentik demi kepastian, perlindungan hukum, antara akta otentik yang dibuat oleh atau di hadapan Notaris adalah alat bukti yang memuat aspek lahiriah, formal dan materiil sebagai wujud kesempurnaan dari akta otentik yang sah di mata hukum dan siapapun dilarang menafsirkan lain mengenai apa yang dinyatakan dalam akta otentik.

Dengan kata lain Kedudukan Notaris sebagai pejabat umum, dalam pengertian mempunyai wewenang dengan pengecualian. Dengan mengkategorikan Notaris sebagai pejabat publik.Dalam hal ini publik yang bermakna hukum, bukan publik sebagai khalayak umum. Notaris sebagai pejabat publik produk akhirnya yaitu akta otentik, yang dalam pelaksanaan tugasnya harus selalu mendasarkan kepada Undang - Undang Nomor 2 Tahun 2014 Tentang Perubahan atas Undang - Undang Nomor 30 Tahun 2004 Tentang Peraturan Jabatan Notaris, yang terikat dalam ketentuan hukum perdata terutama dalam hukum pembuktian.

\section{Ruang Lingkup Tugas Jabatan Notaris dan Produknya}

Undang - Undang Jabatan Notaris telah memberikan kewenangan kepada Notaris sebagai pejabat umum dalam pasal 15 Undang - Undang Nomor 2 Tahun 2014 Tentang Perubahan Undang - Undang 30 Tahun 2004 Tentang Jabatan Notaris adalah sebagai berikut:

1. Notaris berwenang membuat akta otentik mengenai semua perbuatan, perjanjian, dan ketetapan yang diharuskan oleh peraturan perundang-undangan dan/atau yang dikehendaki oleh yang berkepentingan untuk dinyatakan dalam akta otentik, menjamin kepastian tanggal pembuatan akta, menyimpan akta, memberikan grosse, salinan dan kutipan akta, semuanya itu sepanjang pembuatan akta - akta itu tidak juga ditugaskan atau dikecualikan kepada pejabat lain atau orang lain yang ditetapkan oleh undang - undang.

2. Notaris berwenang pula : 
a. Mengesahkan tanda tangan dan menetapkan kepastian tanggal surat di bawah tangan dengan mendaftar dalam buku khusus (legalisasi);

b. Membukukan surat - surat di bawah tangan dengan mendaftar dalam buku khusus (waarmerking);

c. Membuat copy dari asli surat - surat di bawah tangan berupa salinan yang memuat uraian sebagaimana ditulis dan digambarkan dalam surat yang bersangkutan;

d. Melakukan pengesahan kecocokan fotocopy dengan surat aslinya;

e. Memberikan penyuluhan hukum sehubungan dengan pembuatan akta;

f. Membuat akta yang berkaitan dengan pertanahan; atau

g. Membuat akta risalah lelang.

3. Selain kewenangan sebagaimana dimaksud pada ayat (1) dan ayat (2), Notaris mempunyai kewenangan lain yang diatur dalam peraturan perundang - undangan.

Adapun produk yang dibuat Notaris diantaranya semua Akta yang dibuat mengenai Perjanjian atau Perikatan dan Keadaan (Acte Partij atau Relaas Acte) yang diberikan oleh Negara kepada Notaris selaku Pejabat Umum ( Open Baar Ambtenaar) antara lain mengenai

1. Jual Beli Kapal / Pesawat Udara

2. Pendirian PT. PMA ( Penanaman Modal Asing )

3. Jual Beli Bangunan Di tanah Negara

4. Perjanjian Sewa Menyewa

5. Perjanjian BOT ( Build Over Transfer )

6. Pendirian PT (Perseroan Terbatas), Pembubaran PT, Penggabungan PT

7. Pendirian CV, Keluar masuk Persero
8. Kuasa Menjual

9. Rapat Umum Pemegang Saham

10. Novasi

11. Perjanjian Kredit

12. Personal Guarantee

13. Sindikasi

14. Legalisasi, Warmaking

15. Fidusia, Cessie

16. Pendirian Koperasi (untuk hal ini Notaris harus mempunyai Sertifikat dari Menteri Koperasi \& UKM

Dengan demikian, Notaris sebagai pejabat umum diangkat oleh pemerintah dan pemerintah sebagai Organ Negara mengangkat Notaris bukan semata untuk kepentingan Notaris itu sendiri, melainkan juga untuk kepentingan masyarakat luas. Jasa yang diberikan oleh Notaris terkait erat dengan persoalan trust ( kepercayaan diantara para pihak ), artinya Negara memberikan kepercayaan yang besar terhadap Notaris dan dengan demikian dapat dikatakan bahwa pemberian kepercayaan kepada Notaris berarti bahwa Notaris itu mau tidak mau telah memikul tanggung jawab atasnya.

\section{Tanggung Gugat Notaris Terhadap Akta yang Dibuat}

Ada dua istilah yang menunjuk pada pertanggunggugatan dalam kamus hukum, yaitu liability dan responsibility. Liability merupakan istilah hukum yang luas yang menunjuk hampir semua karakter resiko atau tanggunggugat, yang pasti, yang bergantung atau yang mungkin meliputi semua karakter hak dan kewajiban secara aktual atau potensial seperti kerugian, ancaman, kejahatan, biaya atau kondisi yang menciptakan tugas untuk melaksanakan Undang - Undang.

Responsibility berarti hal yang dapat di- 
pertanggungjawabkan atas suatu kewajiban, dan termasuk putusan, ketrampilan, kemampuan dan kecakapan meliputi juga kewajiban bertanggung jawab atas Undang - Undang yang dilaksanakan.Dalam pengertian dan penggunaan praktis, istilah liability menunjuk pada pertanggungjawaban hukum, yaitu tanggung gugat akibat kesalahanyang dilakukan oleh subyek hukum, sedangkan istilah responsibility menunjuk pada pertanggungjawaban politik. ${ }^{4}$ Bertanggung gugat juga berani menanggung segala resiko yang timbul akibat dari pelayanannya itu. Kelalaian dalam melaksanakan profesi menimbulkan dampak yang membahayakan atau mungkin merugikan diri sendiri, orang lain dan berdosa kepada Tuhan. ${ }^{5}$

Tanggung Gugat Notaris Dari Segi Hukum Perdata ialah Ganti rugi atas dasar perbuatan melanggar hukum di dalam hukum perdata diatur dalam Pasal 1365 KUHPerdata, yang menentukan: "Tiap perbuatan melanggar hukum yang membawa kerugian kepada orang lain, mewajibkan orang yang karena salahnya menerbitkan kerugian itu, menggantikan kerugian tersebut. Apabila memperhatikan ketentuan Pasal 1365 KUHPerdata di atas, di dalamnya terkandung unsur - unsur sebagai berikut :

a. Perbuatan yang melanggar hukum

b. Harus ada kesalahan;

c. Harus ada kerugian yang ditimbulkan;

d. Adanya hubungan kausal antara perbuatan dan kerugian.

Perbuatan melanggar hukum diartikan sebagai "berbuat atau tidak berbuat melanggar

4 Ridwan H.R. 2006. Hukum Administrasi Negara, Jakarta : Raja Grafindo Persada, hlm.

5 Abdulkadir Muhamad. 2001. Etika Profesi Hukum. Bandung : Citra Aditya Bakti, hlm 335-337 hak orang lain, atau bertentangan dengan kewajiban hukum orang yang berbuat itu sendiri atau bertentangan dengan kesusilaan atau sikap berhati -hati sebagaimana sepatutnya dalam lalu lintas masyarakat, terhadap diri atau barang - barang orang lain. ${ }^{6}$

Tanggung Gugat Notaris Dari Segi Hukum Administrasi pertanggungjawaban administrasi Notaris merujuk kepada: pertama, tugas dan wewenang; kedua, kewajiban notaris; dan ketiga larangan notaris. Tugas dan wewenang yang dimaksud adalah tugas dan wewenang dalam memenuhi fungsi jabatan sebagai pembuat akta otentik serta segala tindakan dan perbuatan baik yang bersifat prosedural maupun substantif. Tindakan dan perbuatan di luar tugas dan wewenang yang diperintahkan oleh peraturan perundang-undangan berpotensi antara lain: pertama, tidak berwenang (onbevoegdheid: ratione materiele, ratione loci, dan ratione temporis ); kedua, terjadinya penyalagunaan wewenang (abuse of power atau detournement de pouvoir); dan ketiga, kesewenang-wenangan (willikeur). ${ }^{7}$ Jika hal demikian terjadi maka pertanggungjawaban administrasi Notaris tertuju kepada dua hal: pertama, penurunanderajat akta menjadi akta di bawa tangan atau bahkan pembatalan akta oleh pengadilan; dan kedua, pengenaan denda ganti-rugi; dan keti$g a$, pencabutan atau penarikan kembali surat keputusan yang menguntungkan.

Tanggung Gugat Notaris Dari Segi hukum Pidana

Setiap disiplin ilmu memiliki metode dan objek materi tersendiri secara otonom yang

6 Riduan Syahrani. 1998. Seluk Beluk dan Asas-Asas Hukum Perdata. Bandung : Alumni, hlm 264

7 Pihilipus M Hadjon. 2005. Pengantar Hukum Administrasi Indonesia. Gaja Mada. Yogyakarta : University Press, hlm 327 
terpisah dari disiplin lainnya. Dalam melaksanakan tugas dan wewenang jabatan Notaris tidak menutup kemungkinan di dalamnya terjadi penyalagunaan wewenang dengan melekatkan kepentingan pribadi di balik jabatan untuk memperoleh keuntungan pribadi secara melawan hukum pidana seperti memalsukan dokumen dengan membuat akta seakan-akan asli. Seperti diatur dalam Pasal 263 ayat (1) KUHP,

"Barang siapa membuat surat palsu atau memalsukan surat yang dapat menerbitkan suatu hak, suatu perjanjian (kewajiban atau suatu pembebasan utang atau yang boleh dipergunakan sebagai keterangan bagi suatu perbuatan dengan maksud akan menggunakan atau menyuruh orang lain menggunakan surat-sutat seolah-olah surat asli dan tidak dipalsukan, maka kalau menggunakannya dapat mendatang kerugian dihukum"

Demikian halnya dalam Pasal 264 ayat (1) hurud 1e yang merujuk kepada Pasal 266 ayat (1) yang berbunyi:

"Barang siapa menyuruh menempatkan keterangan palsu ke dalam suatu akta otentik tentang suatu kejadian yang kebenarannya harus dinyatakan oleh akta dengan maksud akan menggunakan atau menyuruh orang lain menggunakan akta itu seolah-olah keterangannya itu cocok dengan hal yang sebenarnya".

\section{Akibat Hukum Terhadap Akta Notaris Yang Dibuat Dari Data Yang Tidak Benar \\ Status Hukum dan Kekuatan Hukum Terhadap Akta Notaris}

Menurut Hukum Acara Perdata Pasal 1870 yaitu suatu akta otentik memberikan di antara para pihak beserta ahli waris dan ahli warisnya yang mendapat hak dari mereka, yang mana status hukum terhadap akta Notaris melekat nilai kekuatan pembuktian yang sempurna tentang apa yang dimuat di dalamnya. Artinya apabila akta Notaris yang diajukan memenuhi syarat formil dan materiil serta tidak ada terbukti sebaliknya, maka akta Notaris mempunyai kekuatan pembuktian yang sempurna dan mengikat, sehingga kebenaran isi yang tercantum di dalamnya harus dianggap benar oleh hakim. Dengan nilai kekuatan pembuktian yang sempurna, akta Notaris dapat berdiri sendiri tanpa memerlukan alat bukti lainnya.

Pasal 1869 BW menentukan batasan akta Notaris yang mempunyai kekuatan pembuktian sebagai akta di bawah tangan dapat terjadi jika tidak memenuhi ketentuan karena :

a. Tidak berwenangnya pejabat umum yang bersangkutan;

b. Tidak mampunya pejabat umum yang bersangkutan;

c. Cacat dalam bentuknya Batasan Akta Notaris Menjadi Batal Demi Hukum

Suatu perjanjian yang tidak memenuhi syarat objektif, yaitu objeknya tidak tertentu dan kuasanya terlarang, maka perjanjian tersebut batal demi hukum. Dengan demikian suatu perjanjian batal demi hukum, jika :

a. Tidak mempunyai obyek tertentu yang dapat ditentukan

b. Mempunyai sebab yang dilarang oleh Undang - Undang atau berlawanan dengan kesusilaan atau ketertiban umum.

Daya bukti dari akta otentik mempunyai kekuatan pembuktian yaitu Lahiriah (uitwendigebewijskrachf), Formal (formalebewijskr-acht), Materiil (materielebe-wijskrachf). Ketiga aspek tersebut di atas merupakan kesempurnaan akta Notaris sebagai akta otentik dan siapapun terikat oleh akta tersebut. 
Ketiga aspek tersebut di atas merupakan kesempurnaan akta Notaris sebagai akta otentik dan siapapun terikat oleh akta tersebut. Ketiga aspek tersebut di atas merupakan kesempurnaan akta Notaris sebagai akta otentik dan siapapun terikat oleh akta tersebut.Jika dapat dibuktikan dalam suatu persidangan pengadilan, bahwa ada salah satu aspek tersebut tidak benar, maka akta yang bersangkutan hanya mempunyai kekuatan pembuktian sebagai akta di bawah tangan atau akta tersebut didegradasi kekuatan pembuktiannya sebagai akta yang mempunyai kekuatan pembuktian sebagai akta di bawah tangan.

\section{Akibat Hukum Terhadap Akta Notaris}

Syarat sahnya suatu perjanjian telah diatur di dalam Pasal 1320 KUHPerdata, terdiri dari empat syarat, yaitu sebagai berikut :

1. Sepakat mereka yang mengikatkan dirinya

2. Kecakapan membuat suatu perikatan

3. Suatu hal tertentu

4. Suatu sebab yang halal

Dua syarat pertama dinamakan syarat - syarat subjektif, karena mengenai orang orangnya atau subjeknya yang mengadakan perjanjian, sedangkan dua syarat yang terakhir dinamakan syarat objektif karena mengenai perjanjiannya sendiri oleh objek dari perbuatan hukum yang dilakukan itu.

Sedangkan jika syarat subjektif itu tidak terpenuhi, maka perjanjiannya bukan batal demi hukum, tetapi salah satu pihak mempunyai hak untuk meminta supaya perjanjian itu dibatalkan.Pihak yang dapat meminta pembatalan itu, adalah pihak yang tidak cakap atau pihak yang memberikan sepakatnya secara tidak bebas.Jadi, perjanjian yang telah dibuat itu mengikat juga, selama tidak dibatalkan (oleh hakim) atas permintaan pihak yang berhak meminta pembatalan tadi.Den- gan demikian, nasib suatu perjanjian itu tidaklah pasti tergantung pada kesediaan suatu pihak untuk mentaatinya. ${ }^{8}$

Apabila syarat objektif itu tidak terpenuhi, maka perjanjian itu batal demi hukum. Sedangkan jika syarat subjektif itu tidak terpenuhi, maka perjanjiannya bukan batal demi hukum, tetapi salah satu pihak mempunyai hak untuk meminta supaya perjanjian itu dibatalkan.

Akibat hukum terhadap akta otentik yang mengandung data diri yang palsu berupa buku nikah dan identitas maka akta tersebut telah menimbulkan sengketa dan diperkarakan di sidang pengadilan.Maka oleh pihak yang dirugikan mengajukan gugatan secara perdata untuk menuntut pembatalan agar hakim memutus dan mengabulkan pembatalan akta tersebut.Dengan adanya putusan hakim yang berkekuatan hukum tetap maka dinyatakan akta tersebut batal demi hukum artinya tidak mempunyai kekuatan hukum karena akta tersebut telah cacat hukum sejak perbuatan hukum dan perjanjian akta itu dibuat dan tidak memenuhi unsur - unsur yang ditetapkan Undang - Undang.

\section{Upaya Hukum dilakukan Terhadap Sebuah Putusan}

Pembuatan akta Notaris harus memuat keinginan atau kehendak para pihak yang dituangkan ke dalam isi perjanjian (akta) tersebut. Hal ini diatur dalam Pasal 15 ayat (1) Undang - Undang Nomor 30 Tahun 2004,"Notaris berwenang membuat akta otentik mengenai semua perbuatan, perjanjian, dan ketetapan yang diharuskan oleh peraturan perundang - undangan dan atau yang dikehendaki oleh

8 Susanto Herry. 2010. Peranan Notaris Dalam Menciptakan Kepatutan Dalam Kontrak. Yogyakarta: FH UII Press. Cetakan Pertama 
yang berkepentingan untuk dinyatakan dalam akta otentik, menjamin kepastian pembuatan akta, menyimpan akta, memberikan grosse, salinan dan kutipan akta, semuanya itu sepanjang pembuatan akta - akta itu tidak juga ditugaskan atau dikecualikan kepada pejabat lain atau orang lain yang ditetapkan oleh Undang - Undang. "“

Akta Notaris tidak dapat dinilai atau dinyatakan langsung secara sepihak mempunyai kekuatan pembuktian sebagai akta di bawah tangan atau batal demi hukum oleh para pihak yang namanya dalam akta atau orang lain yang berkepentingan dengan akta tersebut. Jika penggugat dapat membuktikan gugatannya, dan hakim pengadilan memutuskan bahwa akta tidak mempunyai kekuatan pembuktian sebagai akta di bawah tangan atau batal demi hukum, dan hakim membebankan ganti rugi kepada Notaris untuk membayar ganti rugi kepada penggugat, dalam gugatan ini semua tingkat peradilan dapat ditempuh oleh Notaris, sampai ada putusan yang mempunyai kekuatan hukum yang pasti.

Upaya tersebut harus dilakukan agar tidak terjadi penilaian sepihak atas suatu akta Notaris, karena akta Notaris mempunyai kekuatan pembuktian yang sempurna, yang dapat dinilai dari aspek, lahiriah, formal dan materiil. Notaris membuat akta atas dasar permintaan para pihak berdasarkan pada tata cara atau prosedur dalam pembuatan akta oleh Notaris. Ketika para penghadap atau pihak lain yang merasa dirugikan menganggap tidak pada akta tersebut, dan menderita kerugian langsung atas akta tersebut, maka pihak yang bersangkutan menggugat Notaris dan wajib membuktikan, apakah akta Notaris tidak mempunyai aspek lahiriah, formal dan materiil dan membuktikan kerugiannya. Dengan demikian penilaian akta Notaris mem- punyai kekuatan pembuktian akta di bawah tangan atau batal demi hukum tidak dari satu pihak saja, tapi harus dilakukan oleh dan atau dibuktikan di pengadilan.

Jika pengadilan memutuskan akta tersebut mempunyai kekuatan pembuktian akta di bawah tangan atau batal demi hukum, maka atas putusan pengadilan tersebut Notaris dapat dituntut biaya kerugian, ganti rugi dan bunga. Demikian pula jika gugatan tersebut tidak terbukti atau ditolak, maka tidak menutup kemungkinan Notaris yang bersangkutan mengajukan gugatan kepada pihak penggugat.Hal ini sebagai upaya untuk mempertahankan hak dan kewajiban Notaris dalam menjalankan tugas jabatannya, berkaitan dengan akta yang dibuat di hadapan Notaris. ${ }^{9}$

\section{PENUTUP}

Tanggung gugat Notaris terhadap akta yang dibuatnya yang berasal dari data tidak benar oleh penghadap, Notaris bisa di gugat dan turut tergugat jika terbukti bersalah, namun dalam kasus ini penghadap dengan sengaja memalsukan data diri mereka ketika menghadap kepada Notaris, maka Notaris bukan sebagai tergugat dalam hal ini melainkan hanya sebagai saksi atas akta yang telah dibuatnya, dan guna untuk pembatalan akta tersebut didepan pengadilan melalui putusan hakim di pengadilan dimana pihak yang merasa dirugikan menggugat. Notaris hanya merumuskan, apa yang dilihat dan dialaminya dari para penghadap, Notaris tetap berada di luar para pihak atau bukan pihak dalam akta. Dengan kedudukan Notaris seperti itu sehingga jika suatu akta otentik dipermasalahkan, maka tetap kedudukannya sebagai Notaris yang bertindak sesuai dengan Pasal 15 UUJN (kewenangan Notaris), Pasal 16 UUJN (ke-

9 Habieb Adjie.op.cit, hlm 225 
wajiban Notaris dalam membuat akta), Pasal 39 UUJN (tentang syarat penghadap yang datang kepada Notaris), dan Pasal 38 UUJN (tentang format pembuatan akta). Notaris tidak diwajibkan untuk menyelidiki kebenaran isi materiil dari akta otentik dan akta otentik akan menjadi bukti bahwa telah terjadi suatu perbuatan hukum yang dilakukan oleh pihak penghadap.

Akibat hukum terhadap akta Notaris yang berasal dari data diri yang tidak benar menjadi batal demi hukum, karena di dalam isi akta tersebut tidak memenuhi syarat materiil atau syarat objektif didalam Pasal 1320 KUHPerdata yaitu sebab yang halal, Pasal 1335 KUHPerdata " suatu perjanjian tanpa sebab, atau yang telah dibuat karena suatu sebab yang palsu atau terlarang, tidak mempunyai kekuatan" sebab penghadap yang menggunakan data diri mengggantikan foto istri yang sah dengan wanita lain beserta penyesuaian identitas yang palsu ketika menghadap kepada Notaris, jadi data yang disampaikan yang tidak benar bukan penghadapnya.

\section{BIBLIOGRAFI}

Adjie, Habib.2011. Hukum Notaris Indonesia. Bandung: Refika Aditama

Adjie, Habib.2013. Kebatalan Pembatalan Akta Notaris. Bandung: Refika Aditama

H.R. Ridwan. 2006, Hukum Administrasi Negara. Jakarta: Raja Grafindo Persada

M Hadjon Pihilipus.2005. Pengantar Hukum Administrasi Indonesia. Yogyakarta: Gajah Mada University Press.

Marzuki, Pieter Mahmud. 2010. Penelitian Hukum. Jakarta: Kencana.

Muhjad, Hadin dan Nunuk Nuswardani. 2012 .Penelitian Hukum Indonesia Kontemporer.Yogyakarta: Genta Publising.

Muhammad. Abdulkadir .1992, Hukum Peri-
katan.Bandung: Citra Aditya.

Subekti.R. 2005. Hukum Perjanjian. Jakarta: Intermasa.

Tobing, G.H.S. lumban. 1983. Peraturan Jabatan Notaris. Jakarta: Erlangga.

Susanti, Dyah Ochtorina dan A'an Efend.2014. Penelitian Hukum (Legal Research), Jakarta: Sinar Grafika.

Syahrani.Riduan.1998. Seluk Beluk dan AsasAsas Hukum Perdata. Bandung: Alumni. Bandung.

\section{Peraturan Perundang-Undangan}

Kitab Undang - Undang Hukum Perdata

Undang - Undang Nomor 30 Tahun 2004 Tentang Kenotariatan

Undang - Undang Nomor 2 Tahun 2014 Tentang Peraturan Jabatan Notaris

Undang - Undang Nomor 2 Tahun 2014 tentang Perubahan atas Undang - Undang Nomor 30 tahun 2004 tentang Peraturan Jabatan Notaris 